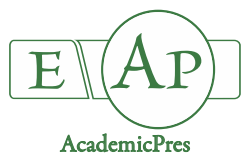

\title{
Seed Treatment Techniques to Improve Germination of Wild Asparagus (Asparagus acutifolius L.), a Potential New Crop
}

\author{
Nikolaos KATSENIOS ${ }^{1 *}$, Ioannis E. ROUSSIS ${ }^{1}$, Aspasia EFTHIMIADOU², \\ Ioanna KAKABOUKI ${ }^{1}$, Dimitrios BILALIS ${ }^{1}$ \\ ${ }^{1}$ Agricultural University of Athens, Department of Crop Science, Laboratory of Agronomy, 75 Iera Odos Str., 11855 Athens, Greece; \\ nkatsenios@gmail.com (“correspondingauthor);iroussis01@gmail.com; i.kakabouki@gmail.com; bilalisdimitrios@gmail.com \\ ${ }^{2}$ Hellenic Agricultural Organization-Demeter, Institute of Soil and Water Resources, Department of Soil Science of Athens, Lycovrisi, \\ Greece; sissyefthimiadou@gmail.com
}

\begin{abstract}
Pre-sowing seed treatment techniques of stratification and scarification were used in order to find the most appropriate method to overcome dormancy of wild asparagus (Asparagus acutifolius L.) seeds. An indoor and an outdoor experiment were carried out at the Agricultural University of Athens. For the indoor experiment, the pre-sowing treatments of stratification (fresh and stratified seeds) and scarification (non-scarified, mechanical scarification and chemical scarification with sulfuric acid) were used as the main treatments, and three different temperatures $\left(15,20\right.$ and $\left.25^{\circ} \mathrm{C}\right)$ as sub-treatments. For the outdoor experiment, there were only the treatments of stratification and scarification. The stratification of asparagus seeds was found to have a positive effect on germination and vigor indices compared to non-stratified (fresh) seeds. The highest germination percentage, vigor index I and II were recorded with the stratified seeds that had been mechanically scarified in both indoor and outdoor conditions. The results indicate that just the scarification cannot improve germination of fresh collected seeds of wild asparagus. Stratification increased the germination percentage from 2.7-6.6\% to 45.1-75.3\%. The mechanical and the chemical scarification had a positive effect on the root length compared to the non-scarified seeds that have been stratified. These presowing treatments can increase the germination percentage and produce vigorous seedlings that can be used to establish plantations of this potential new crop.
\end{abstract}

Keywords: Asparagus acutifolius; germination; scarification; seed dormancy; stratification

\section{Introduction}

Asparagus acutifolius is an evergreen perennial species that is widely distributed in Mediterranean countries of Europe, North Africa, and West Asia. Its edible spears are mainly gathered from wild plants since ancient times. It is probably the species of asparagus that Theophrastus mentioned in his book "Historia Plantarum" as well as Dioscorides reported in his book "De Materia Medica". It has been part of the Mediterranean diet for many years. In recent decades, there is an increasing demand from consumers for wild asparagus spears because of its important nutritional value. However, the collection of the spears from wild plants is a time-consuming process, and for this reason, consumers increase the demand in local markets. In Mediterranean countries, wild asparagus edible shoots are already harvested and marketed (Molina et al., 2012). Moreover, its shoots are considered a source of powerful antioxidants, which could be recovered for use as functional foods or as potential functional ingredients for the food industry (Di Maro et al., 2013). Lately, there is an increasing interest for the peroxidases that the seeds of wild asparagus contain. Guida et al. (2014) found four novel basic peroxidases from Asparagus acutifolius and demonstrated that these enzymes are able to remove phenolic compounds from olive oil mill wastewaters with high efficiency.

For all these reasons, wild asparagus is a potential new crop, which can easily grow under organic farming conditions (Ferrara et al., 2011). Worldwide, there is an escalating interest for the cultivation of species that until recently were considered as weeds because of their increasing importance (Efthimiadou et al., 2012). These shoots are mainly collected from wild plants and, and in many cases, the exploitation is not sustainable, as it is getting more and more intense. For such appreciated species with agronomical potential, the cultivation is increasingly promoted (Molina et al., 2016). Especially wild asparagus 
996

can become a new crop with high income potential, within a sustainable agriculture framework of both biodiversity and environmental conservation (Conversa and Elia, 2009).

Asparagus shoots have been found to have a high content of antioxidants, such as vitamins, carotenoids, and phenolics. Therefore, asparagus is considered a nutritionally well-balanced vegetable, as it has high levels of moisture, ash, proteins, total sugars and linoleic acid, an essential n-6 fatty acid (Martins et al., 2011). The consumption of wild asparagus young shoots is a source of $\mathrm{B}_{9}$ and $\mathrm{E}$ vitamins (Sánchez-Mata et al., 2016). Moreover, the carotenoid content of its edible shoots $\left(175.8 \mathrm{mg} \mathrm{g}^{-1}\right)$ is a richer source than many of the other common leafy vegetables that are commercially available (García-Herrera et al., 2013).

The consumption of the edible parts of wild asparagus could maximize the dietary intake of health beneficial compounds that have protective or disease preventive properties, because of their high content in polyphenols and the significant antioxidant and antiproliferative capabilities (Di Maro et al., 2013). Moreover, the extract of fresh young shoots of wild asparagus was found to have antiinflammatory and adaptogenic effects (Kasture et al., 2009), while the aqueous extract of Asparagus acutifolius had a high pro-apoptotic effect against cancer cell lines because of its various natural bioactive compounds (Bilusic et al., 2019). Fruit and leaves of wild asparagus could be considered as a source of natural agents (phenolic compounds, antioxidant, and cytotoxic activities) for the food and pharmaceutical industry (Kaska et al., 2018).

The plant of Asparagus acutifolius $(2 \mathrm{n}=20)$ is dioecious, green with short rhizome, and its young shoots are sweet or slightly bitter, greenish and elongated (Boubetra et al., 2017). The same authors described that the fruits of the female plants are globose and black, when they are mature, and they have 1-2 seeds, which have a strong dormancy and are difficult to germinate. The increasing interest for the cultivation of wild asparagus has stimulated the research on it. Currently, there is very little information regarding cultivation techniques, which differ from those of cultivated asparagus (A. officinalis) (Benincasa et al., 2007). One major reason that prevents the expansion of wild asparagus is the low levels of seed germination that make difficult the production of seedlings for plant propagation (Conversa and Elia, 2009).

Techniques such as warm and cold stratification and soaking of the seeds have been used in order to improve germination. Conversa and Elia (2009) found that the highest germination parameters [germination percentage, time to $50 \%$ of final germination $\left(T_{50}\right)$, and germination pattern] were obtained when after-ripened seeds for 13 months, were stratified and soaked. These results could be the basis for further research. Currently, there is little research published concerning the mechanisms to overcome dormancy in $A$. acutifolius seeds and further research is needed (Conversa and Elia, 2009). Pre-sowing techniques are very common to improve germination percentage, rate and uniformity of seeds of wild species (AkoumianakiIoannidou et al., 2019), as well as to improve germination on seeds of cultivated species with lower than normal percentages (Bilalis et al., 2012). Researchers have focused their efforts on the use of different pre-sowing methods that are inexpensive and environmentally friendly (Katsenios et al., 2016). Research plantations have found that wild asparagus is suitable for cultivation since it presented an average spear yield of approximately $1300 \mathrm{~kg} \mathrm{ha}^{-1}$, at a plant density of 3.1 and 5 plants $\mathrm{m}^{-2}$ (Benincasa et al., 2007). Monitoring of wild asparagus plants showed that every plant produces 5-12.8 g of spears (Molina et al., 2012).

The aim of this study was to investigate different presowing treatments in order to find the most appropriate method to overcome the dormancy of wild asparagus seeds and increase the germination percentage.

\section{Materials and Methods}

Study site and plant material

A laboratory and a field experiment were established at the Agricultural University of Athens, Greece, in May of 2016. The first experiment took place indoor, under controlled conditions in a CONVIRON germination chamber (Model E15, Controlled Environments Ltd., Winnipeg, Manitoba, Canada). It was carried out in 150 $\mathrm{mm}$ Petri dishes. Twelve seeds were put in each Petri dish. For the second experiment, conducted outdoor, germination trays of 280 positions were used. The substrate was a peat, vermiculite and perlite $(1: 1: 1)$ mixture. Mean daily temperature pertaining to the period of outdoor experiment was obtained from the meteorological station of the Agricultural University of Athens and is presented in Fig. 1.

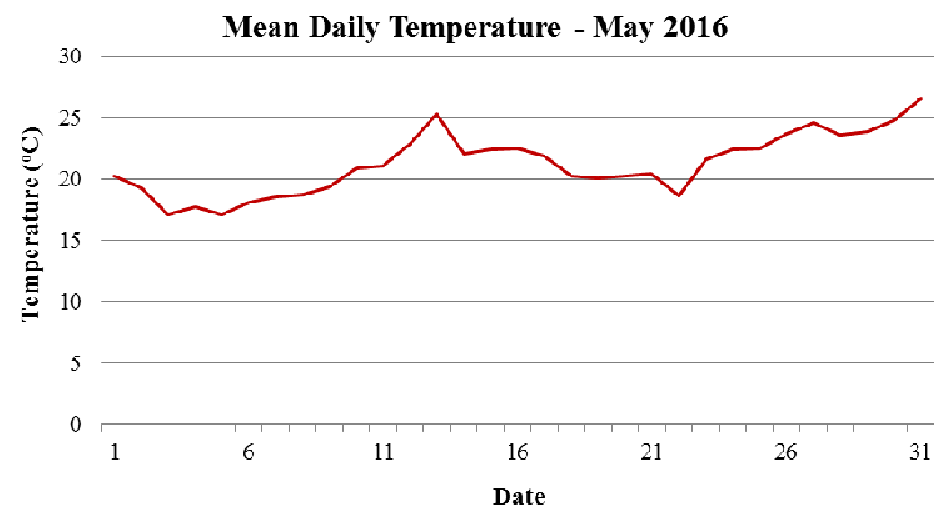

Fig. 1. Mean daily temperature during the experimental period (May 2016) at Agricultural University of Athens, Greece 
The seeds were collected from wild plants in the area of Pentapoli, $\left(38^{\circ} 29^{\prime} 16.3^{\prime \prime} \mathrm{N}, 22^{\circ} 13^{\prime} 01.0^{\prime \prime} \mathrm{E}\right.$, altitude $\left.500 \mathrm{~m}\right)$ in the Prefecture of Phocis, Central Greece.

\section{Experimental design}

For the indoor experiment, the pre-sowing treatments of stratification (fresh seeds: FS, stratified seeds: SS) and scarification (non-scarified: NS, mechanical scarification: MS, chemical scarification with sulfuric acid: SSA) were used as the main treatments and three different temperatures $\left(15,20\right.$ and $\left.25^{\circ} \mathrm{C}\right)$ as sub-treatments. For the outdoor experiment, there were only the treatments of stratification and scarification. Each treatment had ten replications. Non-stratified seeds were fresh seeds collected from wild plants a month before sowing. Stratified seeds were seeds collected a year before, which were refrigerated and stratificated after fully imbibed and then stored at $5{ }^{\circ} \mathrm{C}$ for 12 months. For the mechanical scarification, a knife was used to cut in two positions the seed coat, and for the chemical scarification, $\mathrm{H}_{2} \mathrm{SO}_{4}$ (98\%) was used for 10 minutes.

\section{Measurements and observations}

In both experiments, the germination measurement took place at 30 Days After Sowing (DAS). Seedling length (shoot and root) and dry weight (shoot and root) were also measured at 30 DAS. Vigor index I and II were calculated with the following equations described by Abdul-Baki and Anderson (1973):

Vigor index I $=$ Germination $\% \times$ Seedling length (Root+Shoot) [in cm]

Vigor index II $=$ Germination $\% \times$ Seedling dry weight (Root+Shoot) [in g]

For the measurement of root length, samples from the field experiment were separated from the soil by washing the roots over a $5 \mathrm{~mm}$ mesh sieve. A formalin/acetic acid/alcohol staining solution was used to stain roots of both experiments. The determination of root length was made with a high-resolution scanner using DT software (Delta-T Scan version 2.04, Delta-T Devices Ltd, Burwell, Cambridge, UK) (Kokko et al., 1993).

\section{Statistical analysis}

The experimental data were analyzed using IBM SPSS software ver. 24 (IBM Corp., Armonk, N.Y., USA) according to the completely randomized design (CRD). The significance of the results was tested by one or two-way ANOVA and comparisons of means was calculated using Duncan test at the $5 \%$ level of significance $(\mathrm{p} \leq 0.05)$.

\section{Results and Discussion}

The stratification of asparagus seeds was found to have a positive effect on germination and vigor indices compared to non-stratified (fresh) seeds. The storage of wild asparagus seeds for a one-year period has been found to increase the sensitivity of pre-germination treatments in a similar research study (Conversa and Elia, 2009). On the other hand, the stratification of wild asparagus seeds for just 4 weeks was ineffective in improving germination (Conversa et al., 2010). In all measurements, the seeds that were stratified and had mechanical scarification gave the highest values with statistically significant differences compared to all other treatments. Mechanical scarification is a simple and effective technique to improve seed germination of many species (Hartmann et al., 2011).

The pre-sowing treatment of seeds enhanced germination in both indoor and outdoor conditions with statistically significant differences (Table 1). The highest germination percentage in Petri dishes was found with the stratified seeds. MS treatment (75.33\%) gave the highest values with statistically significant differences to all other treatments (Fig. 2). NS (48.43\%) and SSA (51.70\%) treatments followed with statistically significant differences from all the treatments of fresh seeds. In the outdoor experiment, the highest field emergence was also found in the MS treatment (72.70\%) with statistically significant differences compared to all other treatments. Non-stratified seeds presented very low percentages in both experiments, with values ranging from 2.7 to $6.6 \%$, while stratified seeds had values ranged from 45.1 to $75.3 \%$.

Similar results were obtained by Conversa and Elia (2009), who used non-after-ripened (one-month-old) and after-ripened seeds (dry stored at room temperature for 13 months) and reported that the after-ripened seeds presented higher percentages and more rapid germination. Fresh seeds of wild asparagus were found to germinate at very low percentages, while one-year old seeds that were exposed to different treatments, such as stratification, chemical scarification, and GA3, germinated better (Conversa et al., 2010). The results indicated that the treatment of the seeds with sulfuric acid had a positive effect on germination. A similar effect was found for the species Asparagus racemosus Willd., where the treatment of seeds with sulfuric acid, stimulated seed germination at the levels of $84-86 \%$ (Gupta et al., 2002).

Vigor index I, based on germination percentage and seedling length, showed that the SS-MS treatment gave the highest values for the indoor as well as the outdoor

Table 1. Analysis of variance (F-ratio) in data of indoor and outdoor experiment

\begin{tabular}{|c|c|c|c|c|}
\hline \multicolumn{5}{|c|}{ Indoor experiment } \\
\hline Source & Germination (\%) & Vigor index I & Vigor index II & Root length $^{1}$ \\
\hline Treatment & $474.700^{* * *}$ & $407.234^{* * *}$ & $396.660^{* * *}$ & $74.733^{* * *}$ \\
\hline Temperature & $0.647^{\mathrm{ns}}$ & $0.230^{\mathrm{ns}}$ & $2.733^{\mathrm{ns}}$ & $4.504^{*}$ \\
\hline Treatment*Temperature & $0.777^{\mathrm{ns}}$ & $0.525^{\mathrm{ns}}$ & $0.924^{\text {ns }}$ & $2.020^{\mathrm{ns}}$ \\
\hline \multicolumn{5}{|c|}{ Outdoor experiment } \\
\hline Source & Germination (\%) & Vigor index I & Vigor index II & Root length $^{1}$ \\
\hline Treatment & $140.372^{* * *}$ & $128.887^{* * *}$ & $98.537^{* * *}$ & $5.511^{*}$ \\
\hline
\end{tabular}

Significant at ${ }^{*},{ }^{* *}$ and ${ }^{* * *}$ indicate significance at $\mathrm{p} \leq 0.05,0.01$ and 0.001 , respectively and ns: not significant. ${ }^{1}$ Calculated only for stratified seeds. 


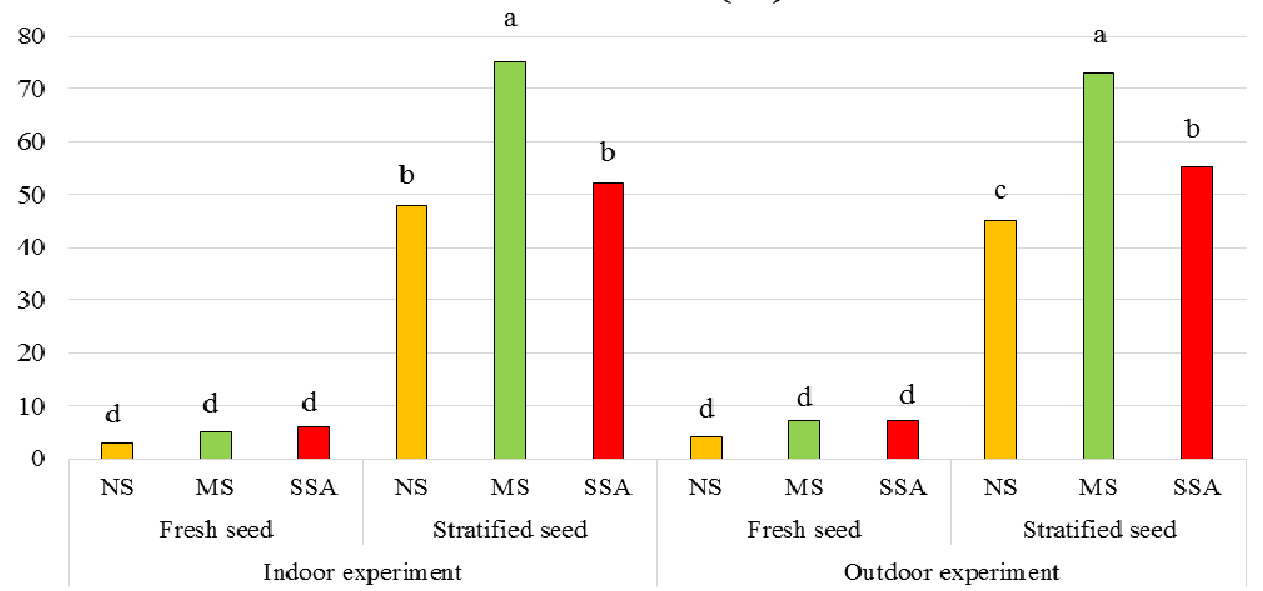

Fig. 2. Effect of pre-sowing treatment of asparagus seeds in indoor and outdoor conditions -means followed by the same letter for treatment are not significantly different according to Duncan test; NS: non scarified; MS: mechanical scarification; SSA: scarification with sulfuric acid

experiment (Table 3). In both experiments, stratified seeds performed statistically better than fresh seeds. Furthermore, for stratified seeds, MS (1492 and 2085) gave statistically significant higher values than NS (949 and 1313) and SSA (1040 and 1598) treatments for the indoor and outdoor experiment, respectively.

Vigor index II, based on germination percentage and seedling dry weight, gave similar results to those of Vigor index I. In both experiments, stratified seeds gave statistically significant better results than fresh seeds. Furthermore, for stratified seeds, MS (20.94) gave statistically higher values than all other treatments. Moreover, SSA (15.77) gave statistically significant higher values than NS (12.69) in the outdoor experiment. In the indoor experiment, for stratified seeds, MS (21.40) gave statistically significant higher values than SSA (14.93) and NS (13.96), but there were no statistical differences between SSA and NS treatments.

Both indices are dependent on the early growth characteristics (length and dry weight) of the new seedlings and give information about how vigorous they are (AbdulBaki and Anderson, 1973). Concerning mechanical scarification, researchers found that it improves early seedling growth characteristics in lupines (Karaguzel et al., 2004). Similarly, acid scarification on fodder sorghum seeds increased the germination and vigor index of the seedlings (Shanmugavalli et al., 2007). In a very interesting research study, the seeds of wild asparagus that passed through bird guts, which is a type of chemical treatment, were found to have a great acceleration of germination compared to nontreated seeds (Traveset et al., 2001).

The measurement of root length ( $\mathrm{mm} / \mathrm{seedling}$ ) took place only for stratified seeds (Table 3 ). For the indoor experiment, the SSA treatment gave the highest value (1581 $\mathrm{mm}$ ) with statistically significant differences compared to MS treatment $(1550 \mathrm{~mm})$, while MS treatment gave statistically significant higher values than NS treatment (1450 mm). Regarding the outdoor experiment, SSA treatment gave the highest value $(1588 \mathrm{~mm})$ with statistically significant differences compared to NS treatment $(1474 \mathrm{~mm})$. MS treatment $(1521 \mathrm{~mm})$ had no statistically significant differences compared to the two other treatments. Mechanical and chemical scarification of certain duration provided the highest values for root length and rood dry weight of lupines compared to control seeds (Karaguzel et al., 2004).

In the indoor experiment, the factor of temperature on seed germination was found to have an effect on root length measurement (Table 2). The highest values of root length were found at the germination temperature of $15^{\circ} \mathrm{C}(1546$ $\mathrm{mm})$, with statistically significant differences compared to $20{ }^{\circ} \mathrm{C}(1519 \mathrm{~mm})$ and $25{ }^{\circ} \mathrm{C}(1516 \mathrm{~mm})$. In a research study on sorghum seeds, where acid scarification was used as a pre-sowing treatment, increased root length of the seedlings was recorded (Shanmugavalli et al., 2007).

Table 2. Effect of temperature at asparagus germination, vigor indices and root length in indoor experiment

\begin{tabular}{ccccc}
\hline Temperature $\left({ }^{\circ} \mathrm{C}\right)$ & Germination $(\%)$ & Vigor index I & Vigor index II & Root length (mm/seedling) \\
\hline 15 & $31.3 \mathrm{a}$ & $622.51 \mathrm{a}$ & $8.59 \mathrm{a}$ & \\
20 & $30.7 \mathrm{a}$ & $614.53 \mathrm{a}$ & $8.83 \mathrm{a}$ & $1546.6 \mathrm{a}$ \\
25 & $32.3 \mathrm{a}$ & $635.08 \mathrm{a}$ & $9.59 \mathrm{a}$ & $1516.1 \mathrm{~b}$ \\
\hline
\end{tabular}

Means followed by the same letter for treatment are not significantly different according to Duncan test. 
Table 3. Effect of pre-sowing treatment of asparagus seeds in indoor and outdoor conditions

\begin{tabular}{|c|c|c|c|c|c|}
\hline \multicolumn{3}{|c|}{ Treatment } & Vigor index I & Vigor index II & $\begin{array}{l}\text { Root length } \\
\text { (mm/seedling) }\end{array}$ \\
\hline \multirow{6}{*}{$\begin{array}{c}\text { Indoor } \\
\text { Experiment }\end{array}$} & \multirow{3}{*}{ Fresh seed } & NS & $55.76 \mathrm{~d}$ & $0.75 c$ & - \\
\hline & & MS & $94.70 \mathrm{~d}$ & $1.35 \mathrm{c}$ & - \\
\hline & & SSA & $110.90 \mathrm{~d}$ & $1.63 \mathrm{c}$ & - \\
\hline & \multirow{3}{*}{ Stratified seed } & NS & $949.56 c$ & $13.96 \mathrm{~b}$ & $1450 \mathrm{c}$ \\
\hline & & MS & $1492.96 \mathrm{a}$ & $21.40 \mathrm{a}$ & $1550 \mathrm{~b}$ \\
\hline & & SSA & $1040.36 \mathrm{~b}$ & $14.93 \mathrm{~b}$ & $1581 \mathrm{a}$ \\
\hline \multicolumn{3}{|c|}{ Treatment } & Vigor index I & Vigor index II & $\begin{array}{l}\text { Root length } \\
\text { (mm/seedling) }\end{array}$ \\
\hline \multirow{6}{*}{ Outdoor Experiment } & \multirow{3}{*}{ Fresh seed } & NS & $116.40 \mathrm{~d}$ & $1.13 \mathrm{~d}$ & - \\
\hline & & MS & $190.70 \mathrm{~d}$ & $2.02 \mathrm{~d}$ & - \\
\hline & & SSA & $201.30 \mathrm{~d}$ & $1.77 \mathrm{~d}$ & - \\
\hline & \multirow{3}{*}{ Stratified seed } & NS & $1313.60 \mathrm{c}$ & $12.69 \mathrm{c}$ & $1474 \mathrm{~b}$ \\
\hline & & MS & $2085.90 \mathrm{a}$ & $20.94 \mathrm{a}$ & $1521 \mathrm{ab}$ \\
\hline & & SSA & $1598.40 \mathrm{~b}$ & $15.77 \mathrm{~b}$ & $1588 \mathrm{a}$ \\
\hline
\end{tabular}

scarification with sulfuric acid

\section{Conclusions}

In conclusion, the results of this study show that the presowing treatments of stratification and scarification can improve germination of wild asparagus. The highest germination percentage, vigor index I and II were recorded with the stratified seeds that had been mechanically scarified in both indoor and outdoor conditions. Stratification increased the germination percentage from $2.7-6.6 \%$ to $45.1-75.3 \%$. The combination of these two pre-sowing techniques could be the appropriate method to overcome dormancy of wild asparagus seeds and increase the germination percentage. Plant propagation is a very important initial step in order to establish plantations of this potential new crop.

\section{Conflicts of interest}

The authors declare that there are no conflicts of interest related to this article.

\section{References}

Abdul-Baki AA, Anderson JD (1973). Vigor determination in soybean by multiple criteria. CropScience 13(6):630-633.

Akoumianaki-Ioannidou A, Gerasimidou E, Salta A, Roussis I, Bilalis D (2019). Sexual and vegetative propagation of Hypericum empetrifolium Willd. subsp. empetrifolium. Notulae Botanicae Horti Agrobotanici Cluj-Napoca 47(2):282-287.

Benincasa P, Tei F, Rosati A (2007). Plant density and genotype effects on wild asparagus (Asparagus acutifolius L.) spear yield and quality. HortScience 42(5):1163-1166.

Bilalis D, Katsenios N, Efthimiadou A, Karkanis A, Efthimiadis P (2012). Investigation of pulsed electromagnetic field as a novel organic presowing method on germination and initial growth stages of cotton. Electromagnetic Biology and Medicine 31(2):143-150.
Bilusic T, Sola I, Rusak G, Poljuha D, Culic VC (2019). Antiproliferative and pro-apoptotic activities of wild asparagus (Asparagus acutifolius L.), black bryony (Tamus communis L.) and butcher's broom (Ruscus aculeatus L.) aqueous extracts against T24 and A549 cancer cell lines. Journal ofFoodBiochemistry 43(4):e12781.

Boubetra K, Amirouche N, Amirouche R (2017). Comparative morphological and cytogenetic study of five Asparagus (Asparagaceae) species from Algeria including the endemic $A$. altissimus Munby. Turkish Journal ofBotany 41(6):588-599.

Conversa G, Elia A (2009). Effect of seed age, stratification, and soaking on germination of wild asparagus (Asparagus acutifolius L.). Scientia Horticulturae 119(3):241-245.

Conversa G, Lazzizera C, Elia A (2010). Effects of after-ripening, stratification and $\mathrm{GA}_{3}$ on dormancy release and on germination of wild asparagus (Asparagus acutifolius L.) seeds. Scientia Horticulturae 125(3):196-202.

Di Maro A, Pacifico S, Fiorentino A, Galasso S, Gallicchio M, Guida V,... Parente A (2013). Raviscanina wild asparagus (Asparagus acutifolius L.): A nutritionally valuable crop with antioxidant and antiproliferative properties. Food Research International 53(1):180-188.

Efthimiadou A, Karkanis A, Bilialis D, Katsenios N (2012). Review: Cultivation of cow cockle (Vaccaria hispanica (Mill.) Rauschert): an industrial-medicinal weed. Industrial Crops and Products 40:307-311.

Ferrara L, Dosi R, Di Maro A, Guida V, Cefarelli G, Pacifico S, ... Parente A (2011). Nutritional values, metabolic profile and radical scavenging capacities of wild asparagus (Asparagus acutifolius L.). Journal of Food Composition and Analysis 24(3):326-333.

García-Herrera P, Cortes Sánchez-Mata M, Cámara M, Tardío J, Olmedilla-Alonso B (2013). Carotenoid content of wild edible young shoots traditionally consumed in Spain (Asparagus acutifolius L., Humulus lupulus L., Bryonia dioica Jacq. and Tamus communis L.). Journal of the Science of Food and Agriculture 93(7):1692-1698. 
1000

Guida V, Cantarella M, Chambery A, Mezzacapo MC, Parente A, Landi N, ... DiMaro A (2014). Purification and characterization of novel cationic peroxidases from Asparagus acutifolius L. with biotechnological applications. Molecular Biotechnology 56(8):738-746.

Gupta S, Kumar A, Sharma SN (2002). Improvement of seed germination in Asparagus racemosus Willd. Journal of Herbs, Spices \& Medicinal Plants 9(1):3-9.

Hartmann HT, Kester DE, Davies FT, Geneve RL (2011). Hartmann \& Kester's Plant Propagation. Principles and Practices (8th Edition), Prentice-Hall, USA.

Karaguzel O, Cakmakci S, Ortacesme V, Aydinoglu B (2004). Influence of seed coat treatments on germination and early seedling growth of Lupinus varius L. Pakistan Journal of Botany 36(1):65-74.

Kaska A, Deniz N, Mammadov R. (2018). Biological activities of wild asparagus (Asparagus acutifolius L.). International Journal of Secondary Metabolite 5(3):243-251.

Kasture S, Kasture A, Ballero M, Maxia A (2009). Antioxidant, antiinflammatory, and adaptogenic activity of Asparagus acutifolius extract. Oriental Pharmacy and Experimental Medicine 9(1):83-89.

Katsenios N, Bilalis D, Efthimiadou A, Aivalakis G, Nikolopoulou AE, Karkanis A, Travlos I (2016). Role of pulsed electromagnetic field on enzyme activity, germination, plant growth and yield of durum wheat. Biocatalysis and Agricultural Biotechnology 6:152-158.

Kokko EG, Volkmar KM, Gowen BE, Entz T (1993). Determination of total root surface area in soil core samples by image analysis. Soil and Tillage Research 26(1):33-43.
Martins D, Barros L, Carvalho AM, Ferreira ICFR (2011). Nutritional and in vitro antioxidant properties of edible wild greens in Iberian Peninsula traditional diet. Food Chemistry 125(2):488-494.

Molina M, Pardo-de-Santayana M, García E, Aceituno-Mata L, Morales R, Tardío J (2012). Exploring the potential of wild food resources in the Mediterranean region: natural yield and gathering pressure of the wild asparagus (Asparagus acutifolius L.). Spanish Journal of Agricultural Research 10(4):1090-1100.

Molina M, Pardo-de-Santayana M, Tardío J (2016). Natural production and cultivation of Mediterranean wild edibles. In: Sánchez-Mata M, Tardío J (Eds). Mediterranean wild edible plants. Springer, New York pp81-107.

Sánchez-Mata M., Matallana-González M, Morales P (2016). The contribution of wild plants to dietary intakes of micronutrients (I): Vitamins. In: Sánchez-Mata M, Tardío J (Eds) Mediterranean Wild Edible Plants. Springer, New Yorkpp 111-139.

Shanmugavalli M, Renganayaki PR, Menaka C (2007). Seed dormancy and germination improvement treatments in fodder sorghum. International Crops Research Institute Semi-Arid Tropics 3:1-3.

Traveset A, Riera N, Mas RE (2001). Passage through bird guts causes interspecific differences in seed germination characteristics. Functional Ecology 15(5):669-675. 